\title{
PENERAPAN MODEL PEMBELAJARAN CONTEXTUAL TEACHING AND LEARNING (CTL) TERHADAP AKTIVITAS SISWA KELAS X DI SMA NEGERI 5 MODEL LUBUKLINGGAU TAHUN PELAJARAN 2018/2019
}

\author{
Srilisnani $^{1}$, Ahmad Amin', Yaspin Yolanda ${ }^{3}$ \\ Alumni Program Studi Pendidikan Fisika STKIP-PGRI Lubuklinggau ${ }^{1}$ \\ Dosen Program Studi Pendidikan Fisika STKIP-PGRI Lubuklinggau ${ }^{2}$ \\ Dosen Program Studi Pendidikan Fisika STKIP-PGRI Lubuklinggau ${ }^{3}$ \\ Email: srilisnani.speed3@gmail.com
}

\begin{abstract}
This research is entitled "The Application of Contextual Teaching And Learning (CTL) Learning Model to the Activities of Class X Students in Lubuklinggau 5 Senior High Schools in Academic Year 2018/2019". The problem in this study is how student learning activities when practicing using CTL learning on the material magnitude and measurement of students of class X MIPA in Lubuklinggau State Senior High School 5 Model 2018/2019. The population in this study were all class X MIPA Lubuklinggau State Senior High School 5 Model 2018/2019 and part of the sample was class X MIPA 4, amounting to 36 students taken randomly. Data collection is done by observation, interviews, questionnaires, and tests. Based on data analysis that 'learning activities at practicum I had a percentage of $76.96 \%$ in good category and at practicum II had a percentage of $85.65 \%$ very good category for students of class X MIPA 4 in Lubuklinggau Model 5 High School 2018/2019.
\end{abstract}

ABSTRAK: Penelitian ini berjudul "Penerapan Model Pembelajaran Contextual Teaching And Learning (CTL) Terhadap Aktivitas Siswa Kelas X Di SMA Negeri 5 Model Lubuklinggau Tahun Pelajaran 2018/2019”. Masalah dalam penelitian ini adalah Bagaimana aktivitas belajar siswa saat praktikum menggunakan pembelajaran CTL pada materi besaran dan pengukuran siswa kelas X MIPA di SMA Negeri 5 Model Lubuklinggau Tahun Pelajaran 2018/2019. Populasi dalam penelitian ini adalah seluruh kelas X MIPA SMA Negeri 5 Model Lubuklinggau Tahun Pelajaran 2018/2019 dan sebagaian sampel adalah kelas X MIPA 4 yang berjumlah 36 siswa yang diambil secara acak. Pengumpulan data dilakukan dengan teknik observasi, wawancara, angket, dan tes. Berdasarkan analisis data bahwa "Aktivitas belajar pada saat praktikum I memiliki persentase $76,96 \%$ kategori baik dan pada saat praktikum II memiliki persentase 85,65\% kategori sangat baik terhadap siswa kelas X MIPA 4 di SMA Negeri 5 Model Lubuklinggau Tahun Pelajaran 2018/2019.

C2019 Physics Departement, STKIP PGRI Lubuklinggau, indonesia

Kata kunci: Penerapan, model pembelajaran CTL dan pembelajaran fisika.

\section{PENDAHULUAN}

Dalam pendidikan formal dan sistem pendidikan Indonesia, salah satu mata pelajaran diajarkan di sekolah adalah fisika. Karena fisika merupakan ilmu yang mempelajari fenomena gejala alam dan tak lepas dari penerapan kehidupan sehari-hari. Pembelajaran fisika merupakan proses antara guru dan siswa yang melibatkan pengembangan pola berpikir dan mengola logika pada suatu lingkungan belajar yang sengaja diciptakan oleh guru dengan berbagai metode agar program belajar fisika tumbuh dan berkembang secara optimal dan siswa dapat melakukan kegiatan belajar secara efektif dan efesien. Pembelajaran fisika yang diberikan tidak hanya transfer pengetahuan tetapi sesuatu yang harus dipahami oleh peserta didik 
yang diperlukan dalam kehidupan seharihari.

Jhonson (2009:31) menyatakan bahwa CTL adalah sebuah sistem yang menyeluruh. CTL terdiri dari bagianbagian yang saling berhubung, jika bagian-bagian ini terjalin satu sama lain, maka akan dihasilkan pengaruh yang melebihi hasil yang diberikan bagianbagian secara terpisah.

Yolanda (2014:27) menyatakan bahwa pembelajaran CTL adalah konsep belajar dimana guru menghadirkan dunia nyata ke dalam kelas dan mendorong siswa membuat hubungan antara pengetahuan yang dimiliki dengan penerapannya dalam kehidupan mereka sehari-hari, sementara siswa memperoleh pengetahuan dan keterampilan dari konteks yang terbatasi sedikit demi sedikit dan dari proses mengkonstruksi sendiri sebagai bekal untuk memecahkan masalah dalam kehidupannya sebagai anggota masyarakat.

Alasan perlu diterapkan pembelajaran Contextual Teaching and Learning (CTL) berdasarkan definisi fisika merupakan ilmu yang mempelajari tentang peristiwa gejala alam sehingga pembelajaran CTL sangat cocok sekali dalam mata pelajaran fisika karena pembelajaran CTL merupakan konsep belajar yang membantu guru mengaitkan antara materi yang diajarkan dengan situasi dunia nyata dapat mendorong siswa membuat hubungan antara pengetahuan yang dimiliki dan penerapannya konsep fisika yang melibatkan keterlibatan siswa secara aktif baik fisik maupun mental akan mendapatkan hasil belajar siswa.

Pembelajaran CTL mempunyai ciri khas tujuh komponen pembelajaran CTL yang terdiri dari konstruktivisme, bertanya, refeleksi, menemukan, pemodelan, kelompok belajar, dan penilaian yang sebenarnnya kemudian tujuh komponen tersebut sangat cocok membantu guru dalam kegiatan belajar mengajar sehingga pembelajaran CTL ini sangat cocok sekali dalam penelitian ini karena peneliti akan mengukur kemampuan aktivitas siswa dalam ranah psikomotor.

Berdasarkan latar belakang yang diuraikan di atas betapa pentingnya model pembelajaran CTL sehingga peserta didik mampu berpikir bisa tahu mengaitkan antara teori dalam kehidupan sehari senada dengan pengertian fisika merupakan ilmu yang mempelajari tentang gejala dan fenomena tujuanya untuk meningkatkan daya pemikiran yang cerdas dan menerapkan suatu teori dalam kehidupan nyata. Maka peneliti tertarik untuk melakukan penelitian yang berjudul "Efektivitas Model Pembelajaran 
Contextual Teaching and Learning (CTL) Terhadap Hasil Belajar pada Materi Besaran dan Pengukuran Siswa Kelas X di SMA Negeri 5 Model Lubuklinggau Tahun Pelajaran 2018/2019”.

\section{KAJIAN TEORITIK}

\section{Aktivitas Belajar}

Kenan (2014:69) menyatakan bahwa aktivitas belajar merupakan prinsip atau asas yang sangat penting dalam interaksi belajar mengajar. Aktivitas belajar adalah suatu aktivitas yang sadar akan tujuan, yaitu terjadinya perubahan (dalam individu seutuhnya. Sedangkan sampurna dalam Targan 2014:58), menyatakan bahwa kegiatan, keaktifan, dan kesibukan. Aktivitas siswa selama proses belajar mengajar merupakan salah satu indikator adanya keinginan siswa untuk belajar.

Dalam penelitian ini, penilaian dalam aktivitas belajar lebih menekankan kepada penilaian unjuk kerja dalam praktikum materi besaran dan pengukuran dengan aspek yang dinilai mengamati percobaan, menggunakan alat percobaan, melakukan percobaan, merapikan alat percobaan, diskusi dengan kelompok, bekerjasama dalam kelompok, menuliskan jawaban LKP, menuliskan data percobaan dalam tabel pengamatan, mendengarkan penjelasan/ informasi guru, dan percaya diri dalam kegiatan pembelajaran.

\section{Pembelajaran CTL}

Hosnan (2016:267) menyatakan bahwa kata contextual berasal dari kata contex, yang bearti "hubungan, konteks, suasana, atau keadaan”. Dengan demikian, contextual diartikan "yang berhubungan dengan suasana (konteks)". Sehingga, CTL dapat diartikan sebagai suatu pembelajaran yang berhubungan dengan suasana tertentu.

Sumiati dan Asra (2007:14) menyatakan bahwa pembelajaran Contextual Teaching and Learning (CTL) mengutamakan pada pengetahuan dan pengalaman atau dunia nyata (real world learning), berpikir tingkat tinggi, berpusat pada siswa, siswa aktif, kritis, kreatif, memecahkan masalah, siswa belajar menyenangkan, mengasyikkan, tidak membosankan (joyfull and quantum learning), dan menggunakan berbagai sumber belajar.

Berdasarkan beberapa definisi pembelajaran CTL tersebut dapat disimpulkan bahwa pembelajaran CTL adalah pendekatan pembelajaran yang mengaitkan antara materi yang dipelajarinya dengan situasi dunia nyata siswa dan mendorong siswa membuat hubungan antara pengetahuan yang di milikinya dengan penerapannya dalam kehidupan sehari-hari dengan melibatkan tujuh komponen pembelajaran efektif. 
Sementara itu, Ditjen Dikdasmen (dalam komalasari 2010:11-12) menyatakan bahwa ada tujuh komponen utama pembelajaran CTL yaitu:

\section{Konstruktivisme (constructivisme)} adalah proses atau menyusun pengetahuan baru dalam struktur kognitif peserta didik berdasarkan pengalaman pribadinya.

2. Menemukan (inquiry) adalah proses pembelajaran yang didasarkan pada pencarian dan penemuan melalui berpikir secara sistematis.

3. Bertanya (questioning), belajar hakikatnya bertanya dan menjawab, bertanya dapat dipandang sebagai refleksi dari keingintahuan setiap individu terhadap sesuatu yang baru.

4. Masyarakat belajar (learning community) adalah kerja sama atau belajar bersama dan sebuah masyarakat atau kelompok.

5. Pemodelan (modelling) adalah pembelajaran dengan memperagakan sesuatu sebagai contoh yang dapat ditiru oleh peserta didik.

6. Refleksi (reflection) adalah proses pengendapan pengetahuan dan pengalaman dilakukan dengan cara mengurutkan kembali kejadiankejadian peristiwa pembelajaran yang telah diprosesnya.
7. Penilaian yang sebenarnya (authentic assesment) adalah proses yang dilakukan guru untuk mengumpulkan informasi tentang perkembangan belajar yang dilakukan oleh siswa.

\section{METOLOGI PENITIAN}

\section{Metode Penelitian}

Menurut Arikunto (2013:203), metode penelitian adalah cara yang digunakan oleh para peneliti dalam mengumpulkan data dalam penelitiannya. Metode dalam penelitian ini adalah metode eksperimen. Rancangan dalam penelitian ini menggunakan pola desain Pre-test and Post-test one grup design karena desain ini tidak menggunakan kelas kontrol. Dalam desain ini tes dilakukan sebanyak dua kali yaitu sebelum eksperimen dan sesudah eksperimen. Tes dilakukan sebelum eksperimen $\left(\mathrm{O}_{1}\right)$ disebut pre-test dan sesudah eksperimen $\left(\mathrm{O}_{2}\right)$ disebut post-test. Menurut Arikunto (2013:124), menyatakan desain penelitian ini dapat lihat pada tabel 3.1.

Tabel 3.1 One Grup Pre-test and Post-test design

\begin{tabular}{lll}
\hline Pre-test & Perlakuan & Post-test \\
\hline $0_{1}$ & $\mathrm{X}$ & $0_{2}$ \\
\hline \multicolumn{3}{c}{ Sumber: Arikunto $(2013: 124)$} \\
Arikunto & $(2013: 159)$, & menyatakan
\end{tabular}

bahwa variabel adalah gejala yang bervariasi, yang menjadi objek penelitian.

Sedangkan menurut Sugiyono (2013:3) 
variabel penelitian adalah suatu atribut atau sifat atau nilai dari orang, obyek atau kegiatan mempunyai variasi tertentu yang ditetapkan oleh peneliti untuk dipelajari dan ditarik kesimpulannya. Penelitian ini terdapat dua variabel, yaitu variabel bebas dan variabel terikat.

a. Variabel bebas (independent), adalah variabel yang mempengaruhi atau yang menjadi sebab perubahannya atau timbulnya variabel dependen (terikat) (Sugiyono, 2013:4). Variabel bebas dalam penelitian ini yaitu model pembelajaran Contextual Teaching and Learning (CTL).

b. Variabel terikat (dependen) adalah variabel yang dipengaruhi atau menjadi akibat, karna adanya variabel bebas (Sugiyono, 2013:4). Variabel terikat dalam penelitian ini yaitu aktivitas dalam praktikum siswa.

\section{Populasi dan Sampel}

\section{Populasi}

Sugiyono (2013:61), menyatakan bahwa Populasi adalah wilayah generalisasi yang terdiri atas objek atau subjek yang mempunyai kualitas dan karakteristik tertentu yang ditetapkan oleh peneliti untuk dipelajari kemudian ditarik kesimpulannya. Sedangkan Arikunto (2013:173), mengemukakan bahwa populasi adalah keseluruhan subjek penelitian. Populasi dalam penelitian ini adalah seluruh siswa kelas X MIPA di SMA Negeri 5 Model Lubuklinggau tahun pelajaran 2018/2019 dapat dilihat pada tabel 3.2.

Tabel 3.2 Populasi Penelitian

\begin{tabular}{lllll}
\hline N & Kelas & \multicolumn{2}{c}{ Jenis Kelamin } & Jumlah \\
\cline { 3 - 4 } o & & $\begin{array}{l}\text { Laki } \\
\text {-laki }\end{array}$ & $\begin{array}{l}\text { Perem } \\
\text { puan }\end{array}$ & Siswa \\
1. & X MIPA & 14 & 23 & 37 \\
& 1 & & 36 \\
2. & $\begin{array}{l}\text { X MIPA } \\
\text { 2 }\end{array}$ & 14 & 22 & 36 \\
3. & X MIPA & 14 & 22 & 36 \\
& $\begin{array}{l}3 \\
\text { 4. }\end{array}$ & & & \\
& $\begin{array}{l}\text { X MIPA } \\
\text { 4 }\end{array}$ & 14 & 22 & 36 \\
& Jumlah & & & 145 \\
\hline
\end{tabular}

\section{Sampel}

Sumber : TU SMA Negeri 5 Model Lubuklinggau (2018/2019)

Menurut Sugiyono (2013:62) sampel adalah bagian dari jumlah dan karakteristik yang dimiliki oleh populasi. Arikunto (2013:174) menyatakan sampel adalah sebagian atau wakil untuk menggeneralisasikan hasil penelitian sampel, yang dimaksud dengan menggeneralisasikan adalah mengangkat kesimpulan penelitian sebagai suatu yang berlaku bagi populasi. Sampel yang digunakan adalah kelas yang diambil acak dengan teknik Simple Random Samplin. Pengambilan sampel dilakukan dengan mengacak empat kelas untuk menjadi sampel tanpa mengacak siswanya.

Tabel 3.3 Sampel Penelitian

\begin{tabular}{|c|c|c|c|c|}
\hline \multicolumn{5}{|c|}{ Jenis Kelamin } \\
\hline $\mathrm{O}$ & mpok & & Laki- $\quad$ Perem & \\
\hline
\end{tabular}




\begin{tabular}{llllll}
\hline & & & laki & puan & \\
1 & Eksp & X & 14 & 22 & 36 \\
. erime & MIP & & & \\
n & A 4 & & & 36 \\
Jumlah & & & & 36 \\
\hline
\end{tabular}

\section{Teknik Pengumpulan Data}

a. Lembar Observasi

Arikunto (2010:272-274) dalai

menggunakan metode observasi cara yang paling efektif adalah melengkapinya dengan format atau blangko pengamatan sebagai instrumen. Format yang disusun berisi item-item tentang kejadian atau tingkah laku yang digambarkan akan terjadi. Dalam melatih pengamatan dilalui dua tahap yaitu:

a. Mendiskusikan format observasi, menjelaskan dengan contoh kejadian dan gerak untuk setiap item, memahami apa yang harus dipahami.

b. Latihan mengamati dan sekaligus mencatat. Kegiatan ini berupa simulasi, dimana salah seorang peserta calon pengamat menjadi model sedangkan yang lain menjadi pengamat dan mengisi format.

Observasi dalam penelitian ini dilakukan untuk mengamati aktivitas siswa pada saat praktikum berlangsung dan melibatkan observer pada masingmasing kelompok dengan setiap observernya mengamati kriteria penilaian yang telah ditentukan pada lembar observasi aktivitas siswa pada saat praktikum.

\section{Validitas dan Reliabilitas Instrumen Penelitian}

\section{a. Validitas}

Arikunto (2013:211) mengemukakan bahwa validitas adalah suatu ukuran yang menunjukan tingkat-tingkat kevalidan atau kesahihan suatu instrumen dan suatu instrumen yang valid atau sahih mempunyai validitas tinggi. Sebaliknya instrumen yang kurang valid berarti memiliki validitas rendah. Teknik kevalidan dengan product moment.

$r_{x y}=\frac{n\left(\sum X Y\right)-\left(\sum X\right)\left(\sum Y\right)}{\sqrt{\left\{n\left(\sum X^{2}\right)-\left(\sum X\right)^{2}\right)\left\{n\left(\sum Y^{2}\right)-\left(\sum Y\right)^{2}\right\}}}$

Keterangan :

$r_{x y}$ : Koefisien korelasi

$X$ : Skor butir soal

$Y$ : Skor total

$n$ : Banyak Subjek

Menurut Jihad dan Haris (2012:180), interprestasi terhadap nilai koefisien korelasi $r_{x y}$ digunakan kriteria Nurgana yaitu dapat dilihat pada tabel 3.5.

Tabel 3.5 Kriteria Validitas

\begin{tabular}{cl}
\hline Kriteria Validitas & Kategori \\
\hline $0,80<\mathrm{r}_{\mathrm{xy}} \leq 1,00$ & Sangat Tinggi \\
\hline $0,60<\mathrm{r}_{\mathrm{xy}} \leq 0,80$ & Tinggi \\
\hline $0,40<\mathrm{r}_{\mathrm{xy}} \leq 0,60$ & Cukup \\
\hline $0,20<\mathrm{r}_{\mathrm{xy}} \leq 0,40$ & Rendah \\
\hline $\mathrm{r}_{\mathrm{xy}} \leq 0,20$ & Sangat Rendah \\
\hline Untuk menentukan & keberartian dari
\end{tabular}

korelasi validitas digunakan uji statistik $\mathrm{t}$ seperti yang dikemukakan oleh Sugiyono (2011:184) dengan rumus : 
$t=\frac{r_{x y} \sqrt{n-2}}{\sqrt{1-r_{x y}^{2}}}$

Distribusi tabel t untuk 5\% $(\alpha=5 \%)$ dan derajat kebebasan $(\mathrm{dk}=\mathrm{n}-2)$ jika $t_{\text {hitung }} \geq t_{\text {tabel }}$ berarti valid dan sebaliknya jika $t_{\text {hitung }}<t_{\text {tabel }}$ maka tidak valid.

\section{b. Reliabilitas}

Arikunto (2013:221) mengemukakan bahwa reliabilitas menunjuk pada satu pengertian bahwa sesuatu instrumen cukup dapat dipercaya untuk dapat digunakan sebagai alat pengumpul data karena instrumen tersebut sudah baik. Instrumen yang sudah dapat dipercaya, yang reliabel akan menghasilkan data yang benar juga. Apabila datanya memang benar sesuai kenyataannya, maka berapa kali pun diambil, tetap akan sama. Menurut Arikunto (2013:239) menyatakan bahwa mengetahui koefisien reliabilitas tes bentuk uraian digunakan rumus alpha sebagai berikut:

$r_{11}=\left[\frac{k}{k-1}\right]\left[1-\frac{\sum \sigma_{b}^{2}}{\sigma_{t}^{2}}\right]$

Keterangan:

$\mathrm{r}_{11} \quad=$ Reliabilitas instrumen

$\mathrm{k}=$ Banyak butir soal

$\sum \sigma_{b}^{2}=$ Jumlah varian skor setiap butir soal

$\sigma_{t}^{2} \quad=$ Varians skor total

Dimana besarnya varians skor total ditentukan dengan rumus:

$\sum \sigma_{b}^{2}=\frac{\sum \mathrm{x}^{2}-\frac{\left(\sum \mathrm{x}\right)^{2}}{n}}{}$
Keterangan:

$\sum \sigma_{b}^{2}=$ jumlah varians butir

$\mathrm{n}=$ Banyak sampel

$\mathrm{X}=$ Skor butir soal masing-masing

Menurut Haris dan Jihad (2012:181), menyatakan bahwa Interprestasi nilai $r_{11}$ mengacu pada Guilford dibagi kedalam kategori dapat dilihat pada tabel 3.7.

Tabel 3.7 Kriteria Reliabilitas

\begin{tabular}{ll}
\hline Kriteria Reliabilitas & Kategori Reliabilitas \\
\hline$r_{11} \leq 0,20$ & Sangat Rendah \\
$0,20<r_{11} \leq 0,40$ & Rendah \\
$0,40<r_{11} \leq 0,70$ & Sedang \\
$0,70<r_{11} \leq 0,90$ & Tinggi \\
$0,90<r_{11} \leq 1,00$ & Sangat Tinggi \\
\hline
\end{tabular}

\section{c. Daya Pembeda}

Daya pembeda soal dari setiap butir soal menyatakan kemampuan suatu soal untuk membedakan antara siswa yang pandai (berkemampuan tinggi) dengan siswa yang kurang pandai (berkemampuan rendah). Menurut Haris dan Jihad (2012:181) Daya pembeda ditentukan dengan rumus berikut:

$\mathrm{DP}=\frac{\mathrm{S}_{\mathrm{A}}-\mathrm{S}_{\mathrm{B}}}{\mathrm{I}_{\mathrm{A}}}$

Keterangan :

DP :Indeks daya pembeda

$\mathrm{S}_{\mathrm{A}}$ : Jumlah skor kelompok atas pada soal yang diolah

$\mathrm{S}_{\mathrm{B}}$ :Jumlah skor kelompok bawah pada soal yang diolah

$\mathrm{I}_{\mathrm{A}}$ :Jumlah skor ideal salah satu kelompok pada butir soal yang diolah

Kriteria indeks daya pembeda yang digunakan menurut Haris dan Jihad dapat dilhat pada tabel 3.9.

Tabel 3.9 Kriteria Interprestasi Daya Pembeda 


\begin{tabular}{ll}
\hline Nilai Daya Pembeda & Kategori \\
\hline 0,40 atau lebih & Sangat Baik \\
\hline $0,30-0,39$ & Baik \\
\hline $0,20-0,29$ & Cukup \\
\hline $0,19-$ kebawah & Jelek \\
\hline
\end{tabular}

(Sumber Jihad dan Haris 2012:181)

\section{d. Tingkat Kesukaran}

Soal yang baik adalah soal yang tidak terlalu mudah dan juga tidak terlalu sukar. Soal yang terlalu mudah, tidak merangsang siswa untuk berpikir tingkat tinggi sehingga motivasi belajar siswa kurang. Menurut Haris dan Jihad (2012:181) Tingkat Kesukaran (TK) pada masing-masing butir soal di hitung dengan menggunakan rumus:

$\mathrm{TK}=\frac{\mathrm{S}_{\mathrm{A}}+\mathrm{S}_{\mathrm{B}}}{\mathrm{nmaks}}$

Keterangan:

TK : Tingkat kesukaran

$\mathrm{S}_{\mathrm{A}}$ : Jumlah skor kelompok atas

$\mathrm{S}_{\mathrm{B}} \quad$ : Jumlah skor kelompok bawah

$\mathrm{n} \quad$ : Jumlah siswa kelompok atas dan bawah

maks:Skor maksimal soal yang bersangkutan

Kriteria tingkat kesukaran digunakan pendapat sudjana (dalam Haris dan Jihad 2012:182) dapat dilihat pada tabel 3.12.

Tabel 3.12 Kriteria Tingkat Kesukaran

\begin{tabular}{ll}
\hline Nilai TK & Kategori \\
\hline $0,00-0,30$ & Sukar \\
$0,31-0,70$ & Sedang \\
$0,71-1,00$ & Mudah \\
\hline \multicolumn{2}{c}{ (Sumber Jihad dan Haris 2012:182) }
\end{tabular}

\section{Teknik Analisis Data}

\section{Analisis data tes}

Analisis data dilakukan untuk mengetahui hipotesis hasil penelitian diterima atau ditolak, maka data diuji dahulu dengan:

a. Mencari nilai rata-rata dan simpangan baku pada tes awal dan tes akhir. Menurut Sugiyono (2013:49 dan 57) menggunakan rumus:

$$
\begin{aligned}
& \bar{x}=\frac{\sum x_{i}}{n} \\
& s=\sqrt{\frac{\sum\left(x_{i}-\bar{x}\right)^{2}}{n-1}}
\end{aligned}
$$

Dimana $\bar{x}$ adalah nilai rata-rata hasil belajar siswa, $x$ i adalah nilai siswa keseluruhan, $\mathrm{n}$ menyatakan bahwa banyak data, dan s adalah simpangan baku.

\section{b. Uji Normalitas}

Menurut Sugiyono (2013:107) uji normalitas ini digunakan untuk mengetahui kenormalan data. Rumus yang digunakan dalam uji normalitas adalah uji kecocokan Chi- Kuadrat $\left(\chi^{2}\right)$. Rumus chi- kuadrat $\left(\chi^{2}\right)$ yaitu:

$\chi^{2}=\sum_{i=1}^{k} \frac{\left(f_{0}-f_{h}\right)^{2}}{f_{h}}$

Dimana, $\chi^{2}$ adalah harga chi-kuadrat yang dicari, $f_{o}$ adalah frekuensi yang diobservasi, $\operatorname{dan} f_{h}$ adalah frekuensi yang diharapkan.

Untuk dapat membuat keputusan tentang hipotesis yang diajukan diterima atau ditolak, maka $\chi_{\text {hitung }}^{2}$ tersebut perlu 
dibandingkan dengan $\chi_{\text {tabel }}^{2}$ dengan derajat kebebasan $(\mathrm{dk})=\mathrm{n}-1$, dimana $\mathrm{n}$ banyaknya kelas interval dan taraf signifikan $5 \%$ atau $(\alpha=0,05)$. Jika $\chi_{\text {hitung }}^{2}<\chi_{\text {tabel }}^{2}$, maka dapat dinyatakan bahwa data berdistribusi normal dan apabila $\chi_{\text {hitung }}^{2}>X_{\text {tabel }}^{2}$ maka distribusinya tidak normal.

\section{c. Uji Hipotesis}

Sugiyono (2012:96) menyatakan bahwa hipotesis merupakan jawaban sementara terhadap rumusan masalah, dimana rumusan masalah penelitian telah dinyatakan dalam bentuk kalimat pertanyaan. Yolanda (2015:3) menyatakan bahwa Hipotesis adalah suatu perkiraan yang beralasan untuk menerangkan suatu kejadian atau pengamatan tertentu. Keterampilan berhipotesis merupakan keterampilan dalam merumuskan teori atau pendapat yang dianggap benar, yang kebenarannya masih harus dibuktikan. Perlu ditekankan bahwa hipotesis berbeda dengan prediksi. Hipotesis didasarkan pada pemahaman suatu teori atau konsep dengan metode deduktif, sedangkan prediksi didasarkan pada data atau pola data dan kecenderungan dengan metode induktif. Sugiyono (2012:250), Uji hipotesis menggunakan uji t, dinyatakan sebagai berikut: $\mathrm{t}=\frac{\bar{x}-\mu_{0}}{\frac{s}{\sqrt{n}}}$

Keterangan:

$\mathrm{t}=$ nilai $\mathrm{t}$ hitung

$\bar{x}=\operatorname{rata}-$ rata $x_{i}$

$\mu_{0}=$ nilai yang dihipotesiskan $\left(\mu_{0}=75\right)$

$S$ = simpangan baku

$n$ = jumlah sampel

Hipotesis yang diujikan adalah:

$\mathrm{H}_{\mathrm{a}}=$ Rata-rata nilai hasil belajar siswa setelah mengikuti pembelajaran fisika dengan model pembelajaran Contextual Teaching and Learning (CTL) lebih dari atau sama dengan $\operatorname{KKM} 75\left(\mathrm{H}_{\mathrm{a}}: \mu_{0} \geq 75\right)$

$\mathrm{H}_{\mathrm{o}}=$ Rata-rata hasil belajar siswa setelah mengikuti pembelajaran fisika menggunakan model Contextual Teaching and Learning (CTL) kurang dari KKM 75. $\left(\mathrm{H}_{\mathrm{a}}\right.$ : $\mu_{0}<75$ ).

d. Penilaian Pada Aktivitas

Sugiyono (2012:137) menyatakan bahwa skor yang telah ditetapkan dapat dihitung sebagai berikut:

Persentase $=\frac{\text { skor yang diperoleh }}{\text { skor maksimum }} \times 100 \%$

Untuk penilaian angket tentang ketercapaian aktivitas siswa:

Skor maksimum $\quad: 10 \times 4=40$

Skala : 4

Rentang skor: $\frac{\text { skor maksimum }}{\text { skala }}=\frac{40}{4}=10$

Persentase dan rentang skor masingmasing angket dapat diperoleh pada tabel 
3.14 dan secara kontinum jumlah seluruh skor dapat digambarkan 3.1.

Tabel 3.14 Persentase Penilaian Ketercapaian Aktivitas

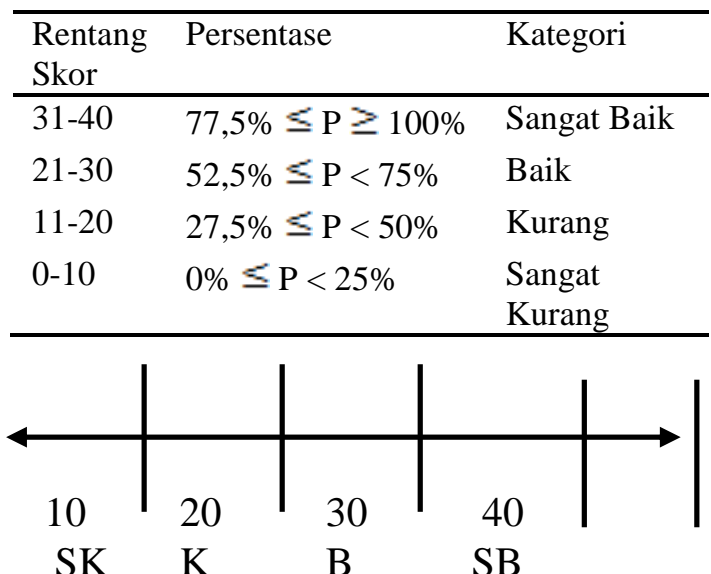

Gambar 3.1 Jumlah Seluruh Skor Persentase Penilaian Ketercapaian Aktivitas

\section{HASIL PENELITIAN DAN}

PEMBAHASAN

\section{Hasil Aktivitas Belajar Siswa}

Observasi dalam penelitian ini digunakan untuk mengetahui aktivitas siswa dalam kelompok pada saat praktikum siswa dengan menggunakan model pembelajaran CTL. Dalam pembelajaran siswa terdiri dari 36 siswa yang dibagi menjadi 6 kelompok.

Aktivitas pada saat praktikum siswa secara berkelompok yang dinilai secara individu oleh obsever selama proses pembelajaran dengan menggunakan model pembelajaran CTL pada pertemuan ke tiga dapat dilihat pada hasil rekapitulasi rubrik akivitas pada saat Praktikum 1 pada tabel 4.5.
Tabel 4.5 Rekapitulasi Rubrik Aktivitas Siswa Pada Saat Praktikum I

\begin{tabular}{|c|c|c|c|c|}
\hline $\begin{array}{l}\mathrm{N} \\
\mathrm{O}\end{array}$ & Uraian & $\begin{array}{l}\text { Jumlah } \\
\text { Siswa }\end{array}$ & $\begin{array}{l}\text { Perse } \\
\text { ntase }\end{array}$ & Kategori \\
\hline 1 & $\begin{array}{l}\text { Aktivitas } \\
\text { Siswa } \\
\text { Sangat Baik }\end{array}$ & 23 & $\begin{array}{l}63,9 \\
\%\end{array}$ & Baik \\
\hline 2 & $\begin{array}{l}\text { Aktivitas } \\
\text { Siswa Baik }\end{array}$ & 10 & $\begin{array}{l}27,8 \\
\%\end{array}$ & Kurang \\
\hline 3 & $\begin{array}{l}\text { Aktivitas } \\
\text { Siswa } \\
\text { kurang }\end{array}$ & 3 & $8,3 \%$ & Kurang \\
\hline 4 & $\begin{array}{l}\text { Rata-rata } \\
\text { Aktivitas } \\
\text { Siswa } \\
\end{array}$ & 36 & $\begin{array}{l}33,3 \\
\%\end{array}$ & Kurang \\
\hline
\end{tabular}

Berdasarkan Rekapitulasi Rubrik Aktivitas Siswa Pada Saat Praktikum II dapat dilihat pada tabel 4.7.

Tabel 4.7 Rekapitulasi Rubrik Aktivitas Siswa Pada Saat Praktikum II

\begin{tabular}{|c|c|c|c|c|}
\hline $\begin{array}{l}\mathrm{N} \\
\mathrm{O}\end{array}$ & Uraian & $\begin{array}{l}\text { Jumlah } \\
\text { Siswa }\end{array}$ & $\begin{array}{l}\text { Persent } \\
\text { ase }\end{array}$ & Kategori \\
\hline 1 & $\begin{array}{l}\text { Aktivita } \\
\text { s Siswa } \\
\text { Sangat } \\
\text { Baik }\end{array}$ & 31 & $86 \%$ & Sangat Baik \\
\hline 2 & $\begin{array}{l}\text { Aktivita } \\
\text { s Siswa } \\
\text { Baik }\end{array}$ & 5 & $14 \%$ & $\begin{array}{l}\text { Sangat } \\
\text { Kurang }\end{array}$ \\
\hline 3 & $\begin{array}{l}\text { Rata- } \\
\text { rata } \\
\text { Aktivita } \\
\text { s Siswa }\end{array}$ & 36 & $50 \%$ & $\begin{array}{l}\text { Kurang } \\
\text { Baik }\end{array}$ \\
\hline
\end{tabular}

Dengan demikian Pada pertemuan pertama diperoleh rata-rata aktivitas pada saat praktikum I dengan nilai persentase sebesar 76,91\% dengan kategori baik, dan rata-rata aktivitas pada saat praktikum II siswa pada pertemuan ke dua dengan nilai persentase sebesar 85,69\%, dengan kategori sangat baik. Hasil observasi dapat dilihat pada tabel 4.8. 
Tabel 4.8 Rekapitulasi Analisis Rubrik Individu

\begin{tabular}{lllll}
\hline Praktikum I & \multicolumn{2}{l}{ Praktikum II } & $\begin{array}{l}\text { Interpre } \\
\text { tasi }\end{array}$ \\
\hline $\begin{array}{l}\text { Keterang } \\
\text { an }\end{array}$ & $\%$ & $\begin{array}{l}\text { Keterang } \\
\text { an }\end{array}$ & $\%$ & Mening \\
Baik & 76,9 & $\begin{array}{l}\text { Sangat } \\
\text { baik }\end{array}$ & 83,7 & kat \\
& $1 \%$ & $9 \%$ & \\
\hline
\end{tabular}

\section{Pembahasan Hasil Penelitian}

Berdasarkan pada rumusan masalah yang dikemukakan dalam penelitian ini yaitu apakah aktivitas belajar siswa saat praktikum menggunakan pembelajaran CTL pada materi besaran dan pengukuran siswa kelas X MIPA di SMA Negeri 5 Model Lubuklinggau Tahun Pelajaran 2018/2019 kategori baik.

Pertemuan pertama siswa disusun ke dalam kelompok yang telah disiapkan dan diberikan LKP sebagai bahan pembelajaran yang akan diselesaikan dengan melakukan eksperimen oleh setiap kelompok. Kemudian sebelum melakukan eksperimen peneliti menjelaskan kembali langkah-langkah dari model pembelajaran CTL yang digunakan agar siswa bisa mengikuti proses pembelajaran dengan baik. Siswa diminta untuk membaca permasalahan yang ada dan memperoleh informasi yang lain dari buku atau sumber lain sehingga memudahkan siswa memeroleh informasi jawaban yang tepat. Dalam pertemuan ini siswa diharapkan siswa lebih aktif dan bisa bekerjasama dengan anggotanya dan peneliti juga mengarahkan kepada siswa tentang apa yang akan dilakukan serta peneliti memberikan setiap kelompok observer yang tentunya membimbing sekaligus menilai siswa tersebut. Dalam pertemuan ini ada salah satu komponen pembelajaran CTL yang diterapkan dalam percobaan tersebut yakni learning community (belajar kelompok) yang tujuannya pengetahuan didapatkan dari hasil kelompok melalui "sharing" dan komponen ini meningkatkan kerja sama dalam kelompok.

Berdasarkan evaluasi dari pertemuan pertama, peneliti menemukan beberapa kendala selama mengikuti pembelajaran dengan menggunakan model pembelajaran CTL yaitu terdapat kelompok yang anggotanya cenderung pasif, hal tersebut kemungkinan karena kurangnya kerjasama anggota kelompok yang mengakibatkan anggota kelompok yang pasif tersebut tidak mampu menyesuaikan diri dengan anggota kelompok lainnya. Proses pembelajaran dengan melakukan kegiatan praktikum pada pembelajaran Fisika baru pertama kali mereka lakukan. Walaupun praktikum ini pertama kali mereka lakukan dari enam kelompok tersebut sebagian besar kelompok mampu bekerjasama dan menggunakan alat 
dengan baik. Hal ini di karenakan keaktifan mereka dan keingintahuan mereka akan hal yang baru. Peneliti bersama-sama siswa mempersentasikan hasil praktikum kedepan kelas dengan di wakili oleh ketua kelompok masingmasing. Barulah pada akhir pembelajaran siswa bersama-sama guru menarik kesimpulan dari materi yang dipelajari pada hari ini. Selanjutnya guru menginstruksikan kepada siswa untuk mempelajari materi pengukuran (massa dan waktu). Adapun rata-rata aktivitas siswa selama proses pembelajaran dengan menggunakan model pembelajaran CTL pada pertemuan pertama dengan nilai persentase $76,91 \%$, dengan kategori baik.

Pertemuan kedua sebelum kegiatan pembelajaran dimulai peneliti menjelaskan kembali langkah-langkah pembelajaran dengan menggunakan model pembelajaran CTL. Hal tersebut bertujuan memberikan pemahaman kepada siswa tentang apa-apa yang harus mereka kerjakan saat mengikuti kegiatan pembelajaran. Sehingga pada setiap pokok permasalahan yang mereka temui di LKP dapat diselesaikan dengan baik dan tepat. Berdasarkan hasil penelitian, kegiatan pembelajaran menggunakan model pembelajaran CTL dapat meningkatkan hasil belajar kognitif, efektif, dan psikomotorik siswa. Hasil penelitian ini sesuai dengan hasil penelitian sebelumnya yang dilakukan Irwan, dkk (2015:8), yang menyimpulkan bahwa terjadi peningkatan yang signifikan pemahaman konsep dan keterampilan praktikum Fisika setelah penerapkan model pembelajaran CTL.

Berdasarkan hasil penelitian, kegiatan pembelajaran menggunakan model CTL dapat meningkatkan hasil belajar berdasarkan pada ranah kognitif hasil persentase kefektifan sebesar 83,3\% dengan kategori sangat baik serta hasil pada ranah psikomotor siswa dengan persentase akhir sebesar $85.69 \%$ dengan kategori sangat baik, serta respon pembelajaran terhadap model pembelajaran CTL didapatkan hasil persentase adalah $86,97 \%$ dengan kategori sangat baik sehingga model CTL ini sangat tepat sekali diterapkan di kelas X MIPA 4

Keterbatasan penelitian adalah kelemahan-kelemahan yang dialami oleh peneliti dalam melaksanakan penelitian ini. Adapun keterbatasan dalam penelitian ini adalah sebagai berikut:

1. Pada penelitian ini hanya dilakukan pada materi besaran dan Pengukuran dalam waktu yang relative singkat, maka diharapkan pada penelitian selanjutnnya untuk dapat 
melaksanakan penelitian pada materi lainnya dan dalam ruang lingkup yang lebih luas serta waktu yang lebih lama.

2. Tidak semua kegiatan siswa teramati dengan baik. Hal ini dikarenakan jumlah siswa yang banyak dalam kelas dan kegiatan siswa tidak dapat diamati dalam waktu yang singkat.

3. Terbatasnya waktu peneliti dalam membagi waktu memberikan bimbingan kepada kelompokkelompok yang mengalami kesulitan dalam mencari solusi mengerjakan lembar kerja praktikum (LKP).

4. Keterbatasan waktu, karena siswa belum terbiasa dalam pembelajaran menggunakan model pembelajaran CTL dengan menggunakan tujuh komponen pembelajaran CTL dan jumlah pertemuan lebih singkat. Diharapkan pada penelitian selanjutnnya untuk menambah jumlah siswa pertemuan yang lebih banyak lagi.

5. Ruang lingkup penelitian, karena peneliti membatasi penelitian pada model pembelajaran CTL dalam materi besaran dan pengukuran. Diharapkan pada peneliti selanjutnnya untuk dapat melaksanakan penelitian pada materi lain dan dengan ruang lingkup yang lebih luas.

\section{KESIMPULAN}

Berdasarkan hasil penelitian dan pembahasan yang telah diuraikan sebelumnnya maka dapat disimpulkan sebagai berikut:

1. Berdasarkan analisis observasi pada pertemuan pertama dengan nilai persentase rata-rata $76,91 \%$, kategori baik dan pada pertemuan kedua dengan nilai persentase rata-rata $85,69 \%$, kategori sangat baik. Maka dapat disimpulkan bahwa aktivitas pada saat praktikum siswa pada proses pembelajaran fisika selama diterapkan menggunakan model pembelajaran Contextual Teaching and Learning (CTL) di kelas X MIPA 4 SMA Negeri 5 Model Lubuklinggau Tahun Pelajaran 2018/2019 meningkat.

\section{DAFTAR PUSTAKA}

Arikonto, Suharsimi. 2013. Prosedur Penelitian. Jakarta: Rineka Cipta.

Arikonto, Suharsimi. 2010. Prosedur Penelitian suatu pendekatan praktek. Jakarta: Rineka Cipta.

Hosnan, M. 2016. Pendekatan Saintifik dan CTL Dalam Pembelajaran Abad 21. Bogor: Ghalia Indonesia.

Jihad, Asep \& Abdul Haris. 2012. Evaluasi Pembelajaran. Yogyakarta: Multi Pressindo.

Johnson, B Elaine. 2009. Contextual Teaching \& Learning. California: Corwin Press.

Kenan, 2014. Upaya Peningkatan Aktivitas Belajar Siswa Melalui Penerapan Metode Penugasan Pada 
Materi Pokok Menulis Di Ke;las IV SD Negeri 050649 Simpngn Pulau Rmbung. Jurnal SainTech.

Komalasari, Kokom. 2010. Pembelajaran CTL Konsep dan Aplikasi. Bandung: PT Refika Aditama.

Sumiati \& Asra. 2007. Metode Pembelajaran. Bandung: CV wacana Prima

Sugiyono. 2013. Metode Penelitian Pendidikan. Bandung: Alfabeta.

Yolanda, Yaspin. 2015. Keterampilan Proses Sains Sebagai Penilaian Pembelajaran Sebagai Implementasi Kurikulum 2013. Prosiding Seminar Nasional Matematika Pendidikan Fisika. 